$14^{\text {th }}$ Conf. Agric. Develop. Res., Fac. of Agric., Ain Shams Univ.,

March, 2019., Cairo, Egypt

Special Issue, 27(1), 193 - 205, 2019

Website: http://strategy-plan.asu.edu.eg/AUJASCI/

\title{
EVALUATING SYMBIOTIC EFFICIENCY OF Mesorhizobium REDUCING SYMPTOMS OF CHICKPEA YELLOW MOSAIC VIRUS
}

\author{
Maryam A. Al-Achtar ${ }^{1,2,3^{*}}$, Girgis ${ }^{1}$ M.G., El-Dougdoug ${ }^{1}$ K.A., \\ Hamwieh $^{2}$ A. and EIDoliefy ${ }^{3}$ A.E.
}

1- Agric. Microbiology Dept., Fac. of Agric., Ain Shams Univ., P.O. Box 68, Hadayek Shobra11241, Cairo, Egypt

2- International Center for Agric. Research in the Dry Area (ICARDA), Biotechnology Dept., Agric. Genetic Engineering Research Institute (AGERI), Giza, Egypt

3- Plant Molecular Biology Dept., Laboratory of Gene Expression and Regulation Technologies, (AGERI), Giza, Egypt.

\section{*Corresponding author: maryamech@hotmail.fr}

Received 9 September, 2018, Accepted 25 September, 2018

\section{ABSTRACT}

Chickpea (Cicer arietinum L.) belongs to legumes reducing atmospheric nitrogen symbiotically through Rhizobia Spp. into proteins in a process leaves no carbon footprint. However, chickpea is highly susceptible to viral diseases, which limits productivity. Therefore, the current study is conducted, in two seasons (2015/2016, 2016/2017) to evaluate the symbiotic efficiency of Mesorhizobia in reducing the damage occurs in chickpea if was infected by chickpea yellow mosaic virus (CpYMV). For this aim, One viral (CpYMV) and two Mesorhizobial isolates (MS3All, MS8All) are isolated from open-fields of chickpea plants. Three chickpea experimental lines (F.07-268, F.07-258 and F.0744) and one Egyptian cultivar (Giza195) are dually infected by CpYMV and either of MS3All and MS8All. Then, infected plants are grown in pots in open-air at the cultivation area of the Faculty of Agriculture, Ain-Shams University (Shoubra). The results indicated that the viral infection led to a reduction in the dry weight of root (DWR) and shoot (DWS), the ratio of root-to-shoot (RSR) dry weight, the nodule counts (NN), the photosynthetic pigments and the nitrogen content $\left(\mathrm{N}_{2}\right)$. Interestingly, the dry weight of nodules (DWN) is significantly increased in dually infected plants. Uniinoculated Chickpea using either of the two isolates of Mesorhizobia showed significant increase in all phenotypic parameters when virus infection is included; except for DWN that decreased com- pared to control viral-infected plants but no mesorhizobia. The current study suggests that bacterial inoculation using Mesorhizobia is significantly reduced damaging effects of the virus on chickpea. Moreover, the MS3All isolate is suggested the more effective than MS8All and the experimental chickpea lines F.07-258 and F.07-44 had the highest significant levels of $\mathrm{N}_{2}$ for shoot than F.07-268 and Giza195 lines.

Keywords: Mesorhizobium sp., Chickpea, Chickpea yellow mosaic virus.

\section{INTRODUCTION}

The symbiosis of rhizobia and legume species is of special importance since it produces about $50 \%$ of the annually worldwide requirements (175 million tons) of total biological $\mathrm{N}_{2}$ fertilizations (Sarıoğlu et al 1993). On one hand, the association between chickpea (Cicer arietinum L.) and Mesorhizobia produces more than $100 \mathrm{~kg} \mathrm{~N} / \mathrm{ha}$ per year depending on the cultivar, the bacterial strain and the environmental factors. On the other hand, chickpea is considered sensitive to viral infections, therefore, viruses are among biotic factors limiting the production and the biological fixation of $\mathrm{N}_{2}$ in chickpea. Several chickpea studies have shown that viral diseases reduce plant growth, $\mathrm{N}_{2}$ fixation, nodule counts, and the percentage of tissue to nitrogen (Horn et al 1995). About 16 viruses have been identified as natural pathogens of chickpea 
including alfalfa mosaic virus, Carlavirus, Ilarvirus, Luteovirus, Nepovirus, Geminivirus, Bromovirus, pea mosaic virus, Potyvirus and Rhabdovirus (Kaiser et al 1990). Several hypotheses are have been suggested to explain the negative influence of the virus on $\mathrm{N}_{2}$ fixation in legumes. Viruses can decrease the supply of photosynthesis outputs to the nodule, decrease the supply of respiratory substrates to the bacteroids, and alter the oxygen diffusion barriers. In addition, viral infection can directly alter photosynthetic carbon metabolism and chlorophyll content as well as the overall efficiency of photosynthesis (Pande, 2015). The genetic variability in rhizobia enabled for tolerance mechanisms to be developed against viral infections. This means, a wide variation exists between the Rhizobial strains of chickpea and its ability to grow and survive under viral infection. For example, using Rhizobial isolates of the same environment showed improved nodulation and $\mathrm{N}_{2}$ fixation than the those of other environments. Hence, this study targets the evaluation of the symbiotic efficiency of some Mesorhizobial isolates on chickpea if challenged by chickpea yellow mosaic virus (CpYMV) infection.

\section{MATERIALS AND METHODS}

The chickpea roots were collected from the chickpea cultivar Giza4 (Fac. of Agric., Ain-Shams Univ.) and the chickpea IP-54247 (Sedes station $A R C)$. Roots were thoroughly washed and the nodules were sectioned and sterilized using 95\% ethanol for $5 \mathrm{~s}$ followed by $3 \%$ of $\mathrm{NaClO}$ for $3 \mathrm{~min}$. Each nodule was crushed and the sap was streaked onto petri dishes containing yeast-extract mannitol agar (YEMA) media (Vincent 1970). The inoculated dishes were incubated at $28^{\circ} \mathrm{C}$ until typical Rhizobial colonies are appeared. Separate colonies were isolated, labeled and purified using repeated streaks on YEMA medium. Selection of colonies is based on uniformity on morphology, absorption of kongo-red $(0.00125 \mathrm{mg} / \mathrm{kg})$, and reaction to Gram staining (Vincent, 1970). The morphological features of colonies included color, mucositis, borders, transparency and elevation. Besides, acid/alkaline reaction was assessed on YEMA medium containing bromothymol blue (BTB$0.00125 \mathrm{mg} / \mathrm{kg}$ ) as an indicator (Alberton et al 2006). Morphological and biochemical characteristics of rhizobial isolates were tested according to Bergey's manual (Jordan, 1984 and Alberton et al 2006).
Molecular identification included the amplification of the 16S rDNA gene of Mesorhizobia (Forward: 5'-AGAGTTTGATCCTGGCTCAG-3', Reverse: 5'-GGTTACCTTGTTACGACTT-3'. The amplicon (1400 bp) is described by Turner et al (1999). DNA was extracted from bacterial isolates using boiling methods (Abdelhai et al 2016). PCR reactions were optimized using the ABApplied Biosystems device: Initial denaturation at $94^{\circ} \mathrm{C}$ for 3 min, 35 cycles of denaturation $\left(94^{\circ} \mathrm{C}\right.$ for $\left.40 \mathrm{~s}\right)$, primer annealing $\left(56^{\circ} \mathrm{C}\right.$ for $\left.50 \mathrm{~s}\right)$, primer extension $\left(72^{\circ} \mathrm{C}\right.$ for $\left.1 \mathrm{~min}\right)$ and final extension $\left(72^{\circ} \mathrm{C}\right.$ for 7 $\mathrm{min}$ ). The amplification products were visualized by electrophoresis. The purified PCR fragments were sequenced (Macrogen, Korea), then BLASTn analysis (Altschul et al 1997) was performed using the NCBI database (www.ncbi.net). The ratio of the similarity between our Egyptian isolates and the top hits on the database was discovered using the MegAlign platform of the Lasergene software (DNAstar). The phylogenetic tree were constructed as an output report from the MegAlign analysis.

\section{Isolation and identification of CpYMV virus}

Symptoms of virus on chickpea plants cultivated in the open-field of Agronomy dept., Fac. of Agric., Ain-Shams Univ. included foliar mosaics, reddening, yellowing, greenness, bunching, stunting, dwarfing, and premature death. Samples were collected. The causing virus was detected serologically by Tissue Blot Immuno-assay (TBIA) (Hampton et al 1990) using specific polyclonal antibody (Provided by Sanofi, Santa, Animal Paris, France) specific for chickpea yellow mosaic potyvirus (CpYMV).

\section{Single-lesion isolation from natural populations}

Crude sap of chickpea (gave positive reaction by serological test) infected with virus was used to inoculate Chenopodium amaranticolor, a locallesion host. Single local lesions that developed 2530 days after inoculation were cut with a sterile razor blade and placed on a glass spatula with a drop $(15 \mu \mathrm{l})$ of $0.01 \mathrm{M}$ sodium phosphate buffer, $\mathrm{pH}$ 7.0. The lesion was then crushed between two glass spatulas and mechanically inoculated to chickpea seedlings at the stage of 3-to-4 true-leaf. Inoculated plants were immediately rinsed with distilled water and kept in the glass house for further examination (Gonsalves and Ishii, 1980). 

of chickpea yellow mosaic virus

\section{Transmission electron microscopy}

A small drop of clarified sap from the CpYMVinfected chickpea was prepared according to Christie et al (1987) and then examined using the JEOL (JEM-2100) TEM electron microscope in Cairo Univ. Research Park, Fac. of Agric.

\section{PCR molecular diagnostics}

Total plant RNA was extracted using GeneZol RNA Extraction Reagent (Genetix), and cDNA was synthesized using the Power cDNA Synthesis Kit (iNtRON Biotechnology). For virus detection, sequences of oligonucleotide primers were designed using the online Primer3-plus tool and the gene sequence of the coat protein listed for the virus (https://www.ncbi.nlm.nih.gov); $\quad$ CpYMVNCBI:txid212424). The forward primer: 5'AGTAGCGACCAAGGAAAGGC-3' and the reverse primer: 5'-CTCTCCGTACTTTCCTCCGC-3'). The expected product is $692 \mathrm{bp}$ fragment. PCR was performed using initial denaturation step at $94^{\circ} \mathrm{C}$ for $3 \mathrm{~min}, 35$ cycles of (denaturation at $94^{\circ} \mathrm{C}$ for 40 $\mathrm{s}$, annealing at $56^{\circ} \mathrm{C}$ for $50 \mathrm{~s}$ and extension at $72^{\circ} \mathrm{C}$ for $1 \mathrm{~min}$ ), then a final extension was performed at $72^{\circ} \mathrm{C}$ for $7 \mathrm{~min}$.

\section{Experimental design}

A total of 24 treatments were generated as a combination between plant, bacteria and virus and laid out in three-stage nested design. The treatments were divided into two main plots $\left(\mathrm{V}_{0}\right.$ and $\mathrm{V}_{1}$ ). The $\mathrm{V}_{1}$ plot expressed the viral application, while the $\mathrm{V}_{0}$ plot expressed the virus-free application (control). Each main plot (V) was subdivided into three subplots $\left(M_{1}, M_{2}\right.$, and $\left.M_{0}\right)$ each consisted of single bacterial applications. The $\left(M_{1}\right)$ subplot included the application of MS3All isolate. The $M_{2}$ subplot included the application of MS8All isolate. The $M_{0}$ subplot included the application of no bacterial infection (control). The four genotypes of chickpeas were then distributed as the experimental units (sub-sub-plots), where the genotypes F.07-268, F.07-258, F.07-44 and the Egyptian cultivar (Giza195) were denoted as $\mathrm{Ch}_{1}, \mathrm{Ch}_{2}, \mathrm{Ch}_{3}$ and $\mathrm{Ch}_{4}$; respectively. The experimental unit in this design is considered by the $\mathrm{VxMxCh}$ unit. The experiment used a total of six replicates and repeated for two seasons (2015/16 and 2016/17).

\section{Bacterial culturing and virus treatment}

The bacterial isolates were cultured in $250 \mathrm{ml}$ Erlenmeyer flasks containing $100 \mathrm{ml}$ of yeastextracted mannitol broth at $28^{\circ} \mathrm{C}$ for 6 days using $160 \mathrm{rpm}$ shaking speed (Prevost et al 1987 and Kantar et al 2003). The chickpea seeds were planted in pots containing about $2 \mathrm{~kg}$ soil (2 seeds/pot). Germinated seeds with $1-2 \mathrm{~cm}$ root length were soaked with bacterial cultures $(2 \mathrm{~mL})$ $\left(10^{8}\right.$ cells $/ \mathrm{mL}$ ) (Öğütçü et al 2008). Chickpea leaves infected with CpYMV isolate gave positive reaction with TBIA assay, were then ground in Phosphate buffered Saline (PBS) buffer and filtrated through two layers of Miracloth. The infectious filtrated sap was used as virus inoculum. After ten days of planting, the plants were inoculated mechanically using the CpYMV infectious sap.

\section{Data collection}

At the flowering stage, the root-nodules were collected and dried at $65^{\circ} \mathrm{C}$ for $24 \mathrm{~h}$. Chlorophyll measurements were performed using fresh leaves and $80 \%$ of Acetone (Arnon, 1949): one (mg) of chlorophyll $(\mathrm{a}+\mathrm{b}) / \mathrm{g}$ tissue $=6.45(\mathrm{~A} 665)+17.72$ (A 649); where $A 665$ and $A 649$ are the absorbance values measured for the extract at $665 \mathrm{~nm}$ and 649 $\mathrm{nm}$ wave length using the spectrophotometer (Tecan's NanoQuant). Other phenotypic data of shoot and root were estimated including the dryweights of the roots (DWR), shoots (DWS) and nodules (DWN). Also, the root-to-shoot ratio (RSR) was calculated. The total nitrogen ( $\mathrm{N}$ content) was also analyzed using the spectrophotometer method (Searle, 1984).

\section{Statistical analysis}

The data were analyzed using GenStat17 platform, where the three major factors in our study are the plant, virus, bacteria and the interaction between them. The variation between treatments of major and interacting factors were estimated using the ANOVA test as (split-split-plot design). The mean values of each phenotypic trait were estimated using the output of ANOVA file analysis. In addition, the least significant differences ( $L S D$ ) test was used to separate between significant mean values at $P=0.05$ and 0.01 . 


\section{RESULTS}

\section{Identified rhizobia}

Two isolates of rhizobia were found to have identical phenotypic characteristics including the circular, elevated convex, white-color, circular shape of colonies and mild mucus production (Table 1). In addition, the two isolates caused acidified changes to the $\mathrm{pH}$ medium, which is been indicated by the change in the BTB dye color from green to yellowish. Also, the diameter for detected colonies ranged between two to five millimeters.

Table 1. Morphological and biochemical characteristics of rhizobia isolates

\begin{tabular}{l|c|c}
\hline Characters & $\begin{array}{c}\text { Isolate } \\
\text { (MS3All)* }\end{array}$ & $\begin{array}{c}\text { Isolate } \\
\text { (MS8All)* }^{\star}\end{array}$ \\
\hline Gram stain reaction & $\begin{array}{c}\text {-ve } \\
\text { Circular } \\
\text { Colony shape }\end{array}$ & $\begin{array}{c}\text {-ve } \\
\text { Circular } \\
+ \text { ve }\end{array}$ \\
Mucocity & Yellow & Yellow \\
Colony color on BTB medium & White & White \\
Colony color on CR medium & + & + \\
Catalase production & + & + \\
Production of HCN & + & + \\
Phosphate solubilization & + & + \\
Production of IAA & +
\end{tabular}

Isolate (MS3All)* from Fac. of Agric. Ain Shams Univ. Isolate (MS8All)* from Sedes - Agric. Res. Cent.

BTB, Bromothymol blue; HCN, Hydrogen cyanide; CR, Congo red dye; IAA, Indole-3 Acetic acid, +ve, positive reaction; -ve, negative reaction.

Two rhizobial isolates did not absorb Congo red. The formation of gas bubbles was noted immediately after the addition of hydrogen peroxide, suggesting that had the enzyme Catalase, were capable of producing IAA, able to produce $\mathrm{HCN}$, had the ability to solubilize phosphate.

Positive results obtained by the phenotypic characterization were encouraged for molecular confirmation using the 16S rDNA gene sequencing. The PCR amplification showed a consistent fragment at the size of 1400 bp (Fig. 1), the PCR product fragment line up in this space1500 bp region leading to believe that the PCR was successful.

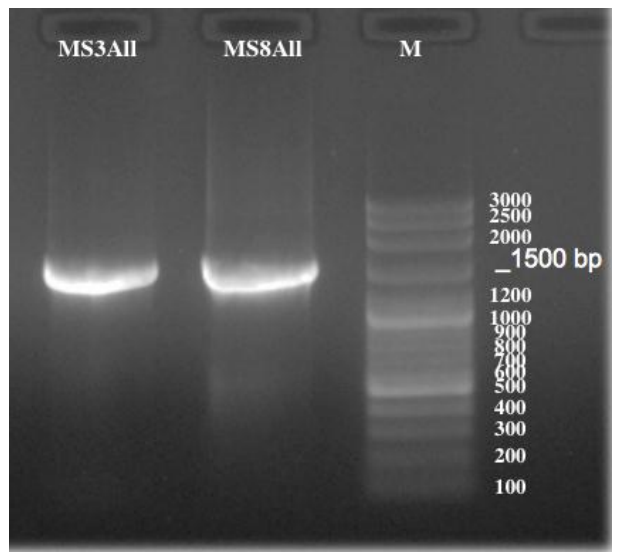

Fig. 1. Agarose gel electrophoresis (1.5\%) showing rhizobial 16SrDNA PCR. Lanes MS3All, PCR product of the MS3All DNA template; Lane MS8All, PCR product of the MS8All DNA template. Lane M, the marker DNA ladder of 100 bp Plus (Vivantis). Amplicon fragment size is $1400 \mathrm{bp}$.

The 16S rDNA sequences were initially analyzed by searching the National Center for Biotechnology Information (NCBI) database using the BLASTn program. Using the MegAlign program, the percentage of identity was calculated between the Egyptian isolates MS3All, MS8All, MS9All and MS10All and the top 10 matching homologs on $\mathrm{NCBI}$ databases identified by the BLASTn analysis (https://www.ncbi.nlm.nih.gov/BLAST/).

Phylogeny tree was created from the 16S rDNA sequences of the Egyptian and the top 10 homologs on the NCBI database. According to the 16SrDNA molecular phylogeny, Egyptian isolates belong to the genus Mesorhizobium, forming a main cluster (Fig. 2.). The sequence identity of the 16SrDNA sequences of these isolates to those of the type strains of Mesorhizobium formed $97 \%$. 


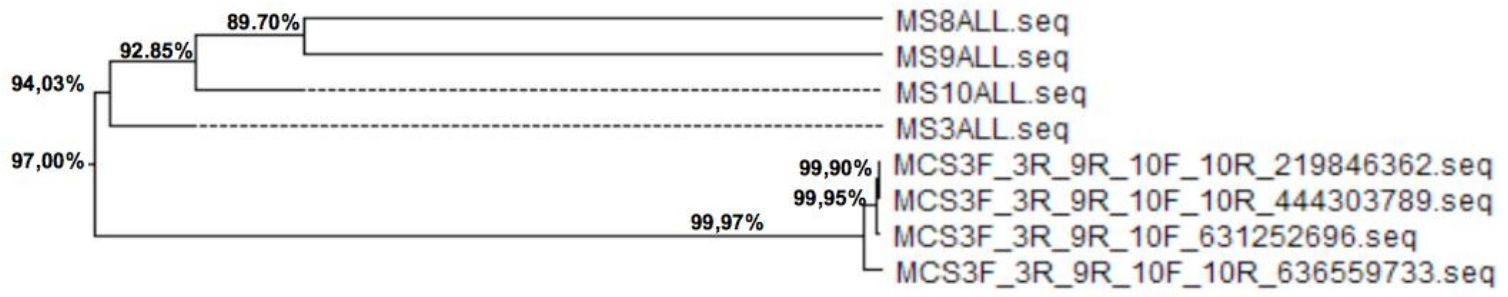

Fig. 2. Phylogeny tree of the Egyptian isolates (MS3All and MS8All) among the top 10 matching homologs on NCBI databases. Percentage of similarity is denoted above each node. MS9All and MS10All are other Egyptian isolates to be tested.

\section{Conformation of Chickpea yellow mosaic virus (CpYMV)}

The CpYMV particles were negatively stained using $2 \%$ uranyl acetate (UA) then examined using the transmission electron microscope (TEM). Filamentous viral particles were detected in the clarified sap preparation (Fig. 3).

Samples were tested by tissue blot immunoassay (TBIA) using the antibody combination for specific detection of potyviruses. The positive TBIA reactions were purple, but green for the noninfected controls (Fig. 4).

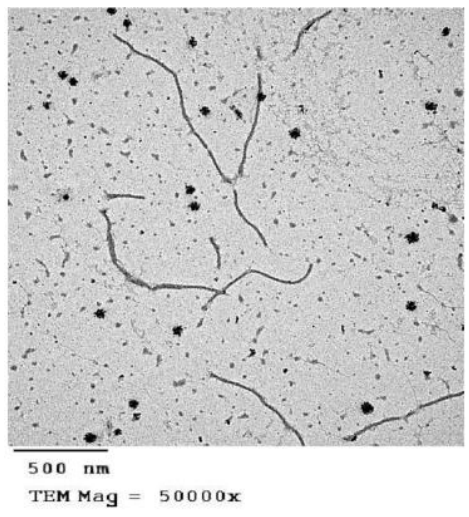

Fig. 3. Photomicrograph of CpYMV virus particles as shown under the TEM.
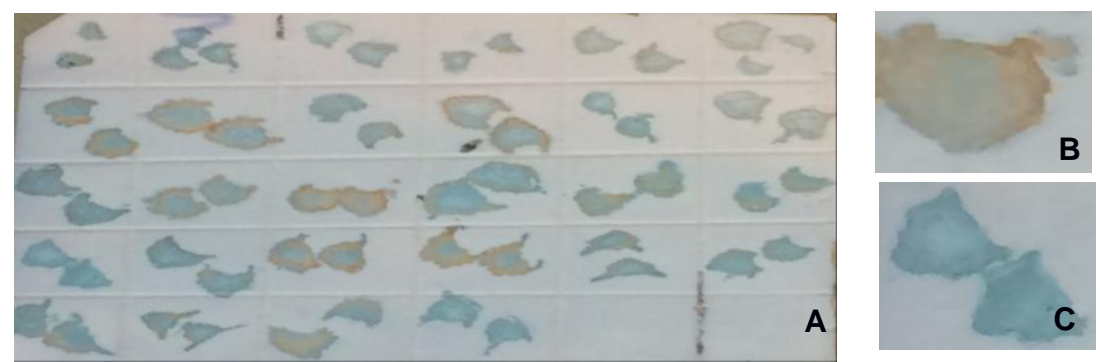

Fig. 4. Photograph nitrocellulose showing Tissue blot immunoassay of CpYMV-infected samples. A, all samples; B, positive immune reaction color; $\mathrm{C}$, negative immune reaction color.

To molecular identified the CpYMV of potyviruses, a specialist primer of coat protein (CP) gene was used for RT-PCR amplification of CP gene sequences from the samples. Identification of virus (CpYMV) was based on the number and the sizes of the products amplified by RT-PCR. In the fig. of gel, The estimated size of the PCR fragment for this band bright lane was to be 700 base pairs, is close from the actual and/or expected value (700 bp) (Fig. 5). 


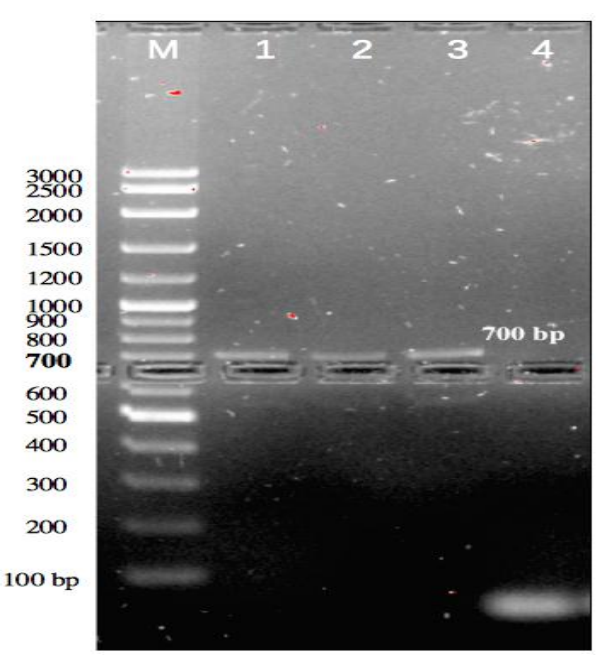

Fig. 5. The cDNA PCR amplification of the CpYMV-induced RNA. The RNA was isolated from leaves of infected chickpea plants. The coat protein gene primers were used to characterize the virus. Lane $\mathrm{M}$, The DNA marker ladder of $100 \mathrm{bp}$ Plus (Vivantis). Lanes 1, 2, and 3 are the PCR amplification of the cDNA template of the CpYMV isolated from infected chickpea. Lane 4 , virus-free infected plants. The amplicon size is $700 \mathrm{bp}$. The concentration of agarose gel electrophoresis is $1.5 \%$ and stained with Red Safe.

\section{Effects of dual rhizobial inoculation and vi- rus infection on chickpea}

\section{Root and shoot dry weights}

Viral infection significantly decreased the dry weights of both roots (28.57\%) and shoots (22\%). The bacterial inoculations (MS3All and MS8All) significantly increased the dry weight of the roots (43.06\% and $31.94 \%)$ and shoots $(64.83 \%$ and $41.16 \%$ ) respectively compared to the uninoculated bacterial control; with bacteria. The interaction effect of "virus $\times$ bacteria" was significant on dry weights of roots and shoots. Inoculated plants with inoculations (MS3All, MS8All) and nonviral had the highest dry weight of the roots $(43.75 \%, 48.75 \%)$ and shoots $(65.25 \%, 32.63 \%)$ by compared to the control (neither bacterial or viral inoculation), respectively with bacteria. While the inoculated plants with inoculations (MS3All, MS8All) and the virus had the highest dry weight $(43.75 \%, 10.94 \%)$ and dry weight $(64.19 \%$, $52.61 \%$ ) by compared to the control (bacteria inoculation, viral infection), respectively with bacteria. The shoots appeared to be more sensitive to viral infection than the roots. Therefore, the interaction effect "virus $\times$ bacteria $\times$ chickpea type" was significant on RSR. The decreases in root-to-shoot ratio (RSR) under treatment were from 0.568 to 0.204 (Tables 2, 3). 

of chickpea yellow mosaic virus

Table 2. Interactive effects of viral infection (CpYMV) and Mesorhizobia inoculations on chickpea genotypes

\begin{tabular}{|c|c|c|c|c|c|c|c|c|c|c|c|c|c|c|}
\hline \multirow[b]{2}{*}{$T$} & \multicolumn{7}{|c|}{ Season $2015 / 16$} & \multicolumn{7}{|c|}{ Season $2016 / 17$} \\
\hline & $\begin{array}{c}\text { DWR } \\
(\mathbf{g} / \\
\text { Plant })\end{array}$ & $\begin{array}{c}\text { DWS } \\
(\mathbf{g} / \\
\text { Plant) }\end{array}$ & RSR & NN & $\begin{array}{c}\text { DWN } \\
(\mathrm{g})\end{array}$ & $\begin{array}{c}\text { Chll } \\
(\mathrm{a}+\mathrm{b}) \\
(\mathrm{mg} / \mathrm{g} \\
\text { tissue })\end{array}$ & \begin{tabular}{|c|} 
TNS \\
$(\mathrm{m}$ \\
$\mathrm{mol} / \mathrm{kg}$ \\
$\mathrm{N})$ \\
\end{tabular} & $\begin{array}{c}\text { DWR } \\
\text { (g/ } \\
\text { Plant) }\end{array}$ & $\begin{array}{c}\text { DWS } \\
(\mathbf{g} / \\
\text { Plant) }\end{array}$ & RSR & NN & $\begin{array}{c}\text { DWN } \\
(\mathrm{g})\end{array}$ & $\begin{array}{c}\text { Chll } \\
(\mathrm{a}+\mathrm{b}) \\
(\mathrm{mg} / \mathrm{g} \\
\text { tissue })\end{array}$ & $\begin{array}{c}\text { TNS } \\
(\mathrm{m} \\
\mathrm{mol} / \mathrm{kg} \\
\mathrm{N})\end{array}$ \\
\hline $\mathrm{V}_{0} \mathrm{M}_{0} \mathrm{Ch}_{1}$ & 0.95 & 1.93 & 0.49 & 4.00 & 0.03 & 5.16 & 0.02 & 0.99 & 2.31 & 0.48 & 11.00 & 0.06 & 6.66 & 0.02 \\
\hline $\mathrm{V}_{0} \mathrm{M}_{0} \mathrm{Ch}_{2}$ & 0.88 & 1.57 & 0.56 & 5.00 & 0.02 & 5.43 & 0.03 & 1.02 & 2.44 & 0.42 & 20.00 & 0.05 & 6.79 & 0.02 \\
\hline $\mathrm{V}_{0} \mathrm{M}_{0} \mathrm{Ch}_{3}$ & 0.64 & 1.75 & 0.37 & 7.00 & 0.04 & 5.44 & 0.02 & 0.91 & 3.78 & 0.24 & 21.00 & 0.02 & 7.40 & 0.02 \\
\hline $\mathrm{Ch}_{4}$ & 0.60 & 1.97 & 0.31 & 8.00 & 0.05 & 5.88 & 0.02 & 0.39 & 2.35 & 0.17 & 13.00 & 0.13 & 5.60 & 0.02 \\
\hline $\mathrm{V}_{0} \mathrm{M}_{1} \mathrm{Ch}_{1}$ & 0.70 & 2.40 & 0.29 & 11.00 & 0.04 & 6.45 & 0.04 & 1.28 & 3.85 & 0.39 & 45.00 & 0.11 & 5.80 & 0.03 \\
\hline $\mathrm{V}_{0} \mathrm{M}_{1} \mathrm{Ch}_{2}$ & 1.06 & 2.38 & 0.45 & 24.00 & 0.07 & 5.92 & 0.04 & 1.21 & 5.58 & 0.22 & 37.00 & 0.08 & 6.89 & 0.03 \\
\hline $\mathrm{V}_{0} \mathrm{M}_{1} \mathrm{Ch}_{3}$ & 1.09 & 2.21 & 0.49 & 31.00 & 0.06 & 5.61 & 0.04 & 1.84 & 7.31 & 0.25 & 40.00 & 0.14 & 9.20 & 0.03 \\
\hline $\mathrm{Ch}_{4}$ & 1.10 & 2.75 & 0.40 & 9.00 & 0.04 & 5.98 & 0.04 & 0.93 & 3.43 & 0.28 & 37.00 & 0.18 & 5.67 & 0.03 \\
\hline $\mathrm{V}_{0} \mathrm{M}_{2} \mathrm{Ch}_{1}$ & 1.15 & 2.38 & 0.48 & 5.00 & 0.03 & 6.69 & 0.04 & 1.16 & 3.56 & 0.34 & 39.00 & 0.09 & 8.04 & 0.03 \\
\hline $\mathrm{V}_{0} \mathrm{M}_{2} \mathrm{Ch}_{2}$ & 1.09 & 2.16 & 0.50 & 8.00 & 0.07 & 5.85 & 0.04 & 2.10 & 3.44 & 0.63 & 33.00 & 0.08 & 8.44 & 0.03 \\
\hline $\mathrm{V}_{0} \mathrm{M}_{2} \mathrm{Ch}_{3}$ & 0.99 & 2.11 & 0.47 & 11.00 & 0.06 & 5.86 & 0.03 & 1.23 & 4.96 & 0.26 & 39.00 & 0.14 & 7.98 & 0.03 \\
\hline $\mathrm{Ch}_{4}$ & 0.91 & 2.34 & 0.39 & 10.00 & 0.05 & 4.63 & 0.03 & 0.94 & 3.06 & 0.31 & 36.00 & 0.16 & 7.28 & 0.03 \\
\hline $\mathrm{V}_{1} \mathrm{M}_{0} \mathrm{Ch}_{1}$ & 0.72 & 1.41 & 0.51 & 4.00 & 0.16 & 1.40 & 0.01 & 0.65 & 2.07 & 0.32 & 10.00 & 0.59 & 1.51 & 0.01 \\
\hline $\mathrm{V}_{1} \mathrm{M}_{0} \mathrm{Ch}_{2}$ & 0.80 & 1.41 & 0.59 & 5.00 & 0.14 & 1.72 & 0.03 & 0.50 & 2.32 & 0.22 & 12.00 & 0.28 & 1.88 & 0.00 \\
\hline $\mathrm{V}_{1} \mathrm{M}_{0} \mathrm{Ch}_{3}$ & 0.51 & 1.47 & 0.35 & 4.00 & 0.13 & 2.50 & 0.01 & 1.06 & 1.82 & 0.63 & 13.00 & 0.56 & 1.48 & 0.02 \\
\hline $\mathrm{V}_{1} \mathrm{M}_{0} \mathrm{Ch}_{4}$ & 0.38 & 1.71 & 0.22 & 8.00 & 0.10 & 2.76 & 0.01 & 0.47 & 1.26 & 0.38 & 6.00 & 0.26 & 1.59 & 0.02 \\
\hline $\mathrm{V}_{1} \mathrm{M}_{1} \mathrm{Ch}_{1}$ & 1.00 & 2.16 & 0.47 & 8.00 & 0.04 & 4.84 & 0.03 & 1.09 & 2.99 & 0.37 & 34.00 & 0.17 & 6.21 & 0.02 \\
\hline${ }_{1} \mathrm{Ch}_{2}$ & 0.61 & 1.99 & 0.31 & 11.00 & 0.09 & 6.00 & 0.04 & 1.23 & 3.43 & 0.37 & 33.00 & 0.18 & 8.76 & 0.03 \\
\hline $\mathrm{V}_{1} \mathrm{M}_{1} \mathrm{Ch}_{3}$ & 0.82 & 1.87 & 0.44 & 9.00 & 0.06 & 5.73 & 0.03 & 0.69 & 4.95 & 0.14 & 34.00 & 0.24 & 7.65 & 0.02 \\
\hline $\mathrm{V}_{1} \mathrm{M}_{1} \mathrm{Ch}_{4}$ & 0.83 & 2.06 & 0.40 & 5.00 & 0.05 & 5.33 & 0.03 & 1.05 & 2.68 & 0.41 & 34.00 & 0.21 & 5.21 & 0.02 \\
\hline $\mathrm{V}_{1} \mathrm{M}_{2} \mathrm{Ch}_{1}$ & 0.82 & 2.15 & 0.38 & 6.00 & 0.13 & 6.30 & 0.03 & 1.02 & 2.61 & 0.39 & 22.00 & 0.21 & 6.18 & 0.02 \\
\hline $\mathrm{Ch}_{2}$ & 0.62 & 1.82 & 0.34 & 8.00 & 0.10 & 6.48 & 0.04 & 0.82 & 3.33 & 0.25 & 32.00 & 0.21 & 8.73 & 0.03 \\
\hline $\mathrm{V}_{1} \mathrm{M}_{2} \mathrm{Ch}_{3}$ & 0.70 & 1.81 & 0.39 & 7.00 & 0.09 & 6.58 & 0.02 & 0.76 & 4.16 & 0.18 & 33.00 & 0.37 & 5.61 & 0.02 \\
\hline $\mathrm{V}_{1} \mathrm{M}_{2} \mathrm{Ch}_{4}$ & 0.59 & 2.03 & 0.29 & 8.00 & 0.07 & 4.68 & 0.02 & 0.30 & 2.65 & 0.12 & 25.00 & 0.23 & 7.76 & 0.02 \\
\hline
\end{tabular}

T, Treatments. DWR, Dry weight of roots. DWS, Dry weight of shoot. RSR, Root/shoot ratio. NN, Number of nodules. DWN, Dry weight of nodules. Chll $(\mathrm{a}+\mathrm{b})$, Total chlorophyll. TNS, Total nitrogen in shoot. V, Virus. M, Mesorhizobia. Ch, Chickpea. 
Table 3. Significance of different phenotypic traits

\begin{tabular}{|c|c|c|c|c|c|c|c|c|c|c|c|c|c|c|}
\hline \multirow[b]{2}{*}{ Factor } & \multicolumn{7}{|c|}{$L S D_{0,05}$} & \multicolumn{7}{|c|}{$L S D_{0,01}$} \\
\hline & DWR & DWS & RSR & NN & DWN & $\begin{array}{c}\text { Chll } \\
(a+b)\end{array}$ & $\begin{array}{c}\text { TNS } \\
(\mathrm{E}-05)\end{array}$ & DWR & DWS & RSR & NN & DWN & $\begin{array}{c}\text { Chll } \\
(a+b)\end{array}$ & $\begin{array}{c}\text { TNS } \\
(\mathrm{E}-05)\end{array}$ \\
\hline V & 0.072 & 0.098 & 0.022 & 1.200 & 0.003 & 0.343 & 9.620 & 0.119 & 0.163 & 0.036 & 1.900 & 0.005 & 0.569 & 15.950 \\
\hline M & 0.045 & 0.259 & 0.034 & 1.200 & 0.005 & 0.480 & 8.350 & 0.062 & 0.357 & 0.047 & 1.600 & 0.007 & 0.661 & 11.500 \\
\hline Ch & 0.066 & 0.220 & 0.045 & 1.800 & 0.006 & 0.619 & 3.490 & 0.087 & 0.292 & 0.059 & 2.400 & 0.008 & 0.822 & 4.630 \\
\hline V.M & 0.078 & 0.306 & 0.042 & 1.600 & 0.006 & 0.603 & 12.060 & 0.109 & 0.419 & 0.058 & 2.200 & 0.008 & 0.823 & 16.570 \\
\hline V.Ch & 0.097 & 0.279 & 0.057 & 2.300 & 0.008 & 0.797 & 9.480 & 0.131 & 0.369 & 0.076 & 3.100 & 0.010 & 1.058 & 13.890 \\
\hline M.Ch & 0.107 & 0.410 & 0.074 & 2.900 & 0.010 & 1.030 & 9.640 & 0.142 & 0.544 & 0.099 & 3.800 & 0.014 & 1.364 & 12.960 \\
\hline V.M.Ch & 0.157 & 0.548 & 0.103 & 4.100 & 0.014 & 1.430 & 13.870 & 0.208 & 0.726 & 0.136 & 5.400 & 0.019 & 1.894 & 18.630 \\
\hline
\end{tabular}

LSD, Least significant difference. DWR, Dry weight of roots. DWS, Dry weight of shoot. RSR, Root/shoot ratio. Chll $(a+b)$, Total chlorophyll . TNS, Total nitrogen in shoot.V, Virus. M, Mesorhizobia. Ch, Chickpea.

\section{Nodule number and nodule dry weight}

The number and dry weight of the nodule were affected by viral infection (Tables 2, 3). As an average viral treatment reduced the number of nodules by $26.79 \%$ and increased nodule dry weight by $167.12 \%$ compared to non-viral conditions (Fig. 2). Nodule number was highest in plants inoculated with culture isolates (MS3All, MS8All) (168.96 and 117.76 number of plants-1, respectively) compared to non-inoculated bacterial control, bacterial inoculations (MS3All, MS8All) significantly increased (165.66 and 107.45 plant-1 numbers, respectively) under non-virus compared to control (neither bacterial nor viral inoculation), and significantly increased by (189.39 and 160.98 number of plant -1 , respectively) under viral infection compared to control (non-bacterial inoculation and viral infection). On the other hand, plants inoculated with isolates culture $(0.109$ and $0.130 \mathrm{~g}$ plant-1, respectively) produced the highest nodule dry weights, and there were significant differences between treatments "Virus $\times$ bacteria $\times$ type of chickpeas". The dry weight of the nodules shows a strong negative correlation $\left(-, 432^{*}\right.$ at the 0.05 level) with the dry weight of the shoots. but the number of nodules showed a positive correlation $\left(0,922^{* *}\right.$ at $\left.p \leq 0.01\right)$ with the DWS.

\section{Chlorophyll content}

The virus also had a detrimental effect on plant chlorophyll content $(\mathrm{a}+\mathrm{b})(24.44 \%$ decrease). As an average of bacterial inoculations (MS3All, MS8All) increased the chlorophyll content of $60.22 \%$ and $69.49 \%$ compared to non-bacterial conditions, respectively. In both "virus $\times$ bacteria" conditions, the highest levels of plant chlorophyll were observed in (MS8All) 13.25\% compared to the uninoculated bacterial plant. Plants inoculated with this isolation increased the chlorophyll content (252.94\%), while the isolate (MS3All) increased the amount of chlorophyll at $(235.35 \%)$ relative to the noninoculation content and infected with the virus of the plant. (Tables 2, 3).

\section{Total nitrogen content}

The total $\mathrm{N}_{2}$ content of the plants and the total $\mathrm{N}_{2}$ plant $^{-1}$ were reduced by the viral infection. Although, viral inoculation reduces the $\mathrm{N}_{2}$ content of the stem by $20.74 \%$, the bacterial inoculation (MS3All, MS8All) increased the $\mathrm{N}_{2}$ content in the shoot by $70.66 \%$ and $50.72 \%$; respectively, compared to the control. Interactive effect of "virus $x$ bacteria" was significant. In the meanwhile, bacterial inoculations (MS3All, MS8All) significantly increased the $\mathrm{N}_{2}$ content $(56.04 \%$ and $40.37 \%$; respectively) under non-virus control. Bacterial isolates significantly reduced the negative effect of 

of chickpea yellow mosaic virus

the virus at the $\mathrm{N}_{2}$ content of the shoot as values increased as $91.96 \%$ and $65.81 \%$; respectively compared to control plants infected with virus but no bacteria (Tables 2, 3).

\section{DISCUSSION}

Viral infections were a negative effect on dry weight of shoot and root. While the effect was positive of the mesorhizobial inoculation. This is consistent with Sharma and Varma (1983), where they observed a decrease in the weight of shoot by the effect of the cowpea banding mosaic virus (CpBMV) in cowpea plants. Gibson (1987) and Ben Romdhane et al (2007) reported that the rhizobial strain inoculation increased the shoot dry weight of the plant. Several studies (Elsheikh and Osman, 1995, Rohani et al 2008, López et al 2016) have reported the negative effect of the virus on the roots of infected plants. Rhizobial inoculation had a positive effect on the roots of rhizobial inoculated plants, and this was consistent with (Elsheikh and Osman, 1995; Al-Ani and Adhab, 2013). Viral infection had a negative effect on the reduction of plant leaf content of chlorophyll $(a+b)$, while the content increased with the effect of mesorhzobial inoculation. The symptoms of CpYMV-induced disease may in part be attributed to the ability of viral replication proteins to disrupt the localization and subsequent function of the auxin / indole acetic acid (Aux/IAA) reaction, according to Padmanabhan et al (2006) in his study on the tobacco mosaic virus. The development of the disease is related to the interaction of viral replicase with Aux/IAA proteins, according to Padmanabhan et al (2005). Recent data suggests that Aux/IAA proteins can induce light responses according to Reed (2001).

Mesorhizobial inoculation increased the content of leaves for total $\mathrm{N}_{2}$ due to the process of fixing nitrogen in the nodules. While the viral infection resulted in a decrease in the content of leaves for $\mathrm{N}_{2}$. This may be due to the effect of the virus on slowing or inhibiting the transfer of $\mathrm{N}_{2}$ fixated in the nodules to other parts of the plant. Decreased growth of virus-infected plants may be due to $\mathrm{N}_{2}$ fixation impaired by nodules (Pande, 2015). Improvement of plant growth due to mesorhizobial inoculation can be explained by the ability of rhizobia to form nitrogen-fixing nodules and release secondary metabolites such as growth regulators, as well as the facilitation of phosphate (Antoun and Prevost 2005, Sahran and Nehra 2011) and the production of rhizobia for iron-chelating sidero- phores compounds (Arora et al 2005). In addition, mesorhizobia stimulate the plant's defense mechanisms by producing compounds with direct antimicrobial activities (Kacem et al 2009).

Viral infections reduced the number of nodules, while they increased their weight. While rhizobia had a highly significant effect on the increase in the number of nodules, and reducing the weight of the nodules infected with the virus to return to acceptable weights. The MS3All mesorhizobia had a positive role of more than MS8All mesorhizobia in that. Rizobia is said to increase the number of nodules (Osman and El-Sheikh, 1994; Ben Romdhane et al 2007; Al-Ani and Adhab, 2013).

The decrease in the number of nodules due to viral infection has been reported in soybean infected with Soybean mosaic virus and Bean pod mottle virus, Sesbania infected with Sesbania mosaic virus, Soybean infected with Yellow mosaic, mungbean infected with Common bean mosaic virus, Cowpea infected with Peanut stunt virus, Cowpea infected with Cowpea vein banding mosaic virus, cowpea infected with Cowpea mosaic virus (Pande, 2015), White Clover infected with white clover mosaic virus (Guy et al 1980), Glycine max L. infected with soybean mosaic virus and bean pod mottle virus (Tu et al 1970), Faba bean infected with broad bean mottle bromovirus and bean yellow mosaic potyvirus (Osman and ElSheikh, 1994). A study has increased the nodulation (Rajagopalan and Raju, 1972). The decrease in the number of nodules in plants infected with viral infection, may be due to, one or both of these, (i) the effect of the virus on the reduction of the release of legume roots to flavonoids, which are commonly known to identify the lipochitooligosaccharide molecules (nod factors) produced from rhizobia. As Hungria et al (1991) explained in his explanation of the concept of nodulation. (ii) the effect of the virus on some of the biochemical signals produced after the recognition of compatible of the root on the nod factors, which include changes in the flow of ions and the spiking of calcium and hormone balance followed by differential gene expression, and the doubling of cortical cells and hair root defects and the formation of infection (Oldroyd and Downie 2008; Masson-Boivin et al 2009; Madsen et al 2010). As Tu et al 1971 shows, the virus replication leads to an imbalance in the levels of auxins, which affects the symbiotic relationship between rhizobia and plant. Decreased effectiveness of of Mesorhizobia with the presence of the virus compared to its absence. 
This is paralleled by the results of JOSHI et al (1967) who similarly succeeded in proving that the virus changed the functions of rhizobia and its numbers in the nodules and the presence of the virus in the nodules. Where the effect of the latter on the accumulation of total nitrogen in the nodules, may be the reason for the high weight of the nodules.

Plants of the genotype (Ch3) gave the highest dry-weight of shoot and therefore the amount of straw was higher than the other studied plants, the least being the local cultivar (Ch4). The leaves of genotype (Ch2) were the highest in chlorophyll and total nitrogen.

On the interactive effect of meshorhizobia and virus, mesorhizobia inoculation significantly increased certain parameters despite viral infection. This means that plants infected with virus produce more severe symptoms of infection when they are not inoculated with mesorhizobia than plants treated with virus and mesorhizobia. The significant increase in the number of nodule and some other indicators of plants inoculated with mesorhizobia compared to non-inoculated plants indicates that the isolates of mesorhizobia contributed significantly to the formation of nodules on plant roots.

\section{REFERENCES}

Abdelhai M.H., Hassanin H.A.M. and Sun, X. 2016. Comparative Study of Rapid DNA Extraction Methods of Pathogenic Bacteria. American J. of Bioscience and Bioengineering. 4, 1-8.

Al-Ani R.A. and Adhab M.A. 2013. Bean Yellow Mosaic Virus (BYMV) on Broadbean: Characterization and Resistance Induced by Rhizobium leguminosarum. J. of Pure and Applied Microbiology 7, 135-142

Alberton O., Kaschuk G. and Hungaria M. 2006. Sampling effects on the assessment of genetic diversity of rhizobia associated with soybean and common bean. Soil Biology and Biochemistry 38, 1298-1307.

Altschul S.F., Madden T.L. and Schäffer A.A. 1997. Gapped BLAST and PSI-BLAST: a new generation of protein database search programs. Nucleic Acids Research 25, 33893402.

Antoun H. and Prevost D. 2005. Ecology of plant growth promoting rhizobacteria. In: Siddiqui, Z.A. (ed.), PGPR: Biocontrol and Biofertilization. Springer, Dordrecht; pp.1-38.
Aron D. 1949. Copper enzymes isolated chloroplasts, polyphenoloxidase in Beta vulgaris. Plant Physiology. 24, 1-15.

Arora S., Chopra A.K., Joshi N. and Prasad G. 2005. Physicochemical and bacteriological characteristics of Aachal dairy mill effluent and its effects on seed germination of some agricultural crops. Nature Environment and Pollution Technology. 4, 441-444.

Ben Romdhane S., Tajini F., Trabelsi M., Aouani M. and Mhamdi R. 2007. Competition for nodule formation between introduced strains of Mesorhizobium ciceri and the native populations of rhizobia nodulating chickpea (Cicer arietinum) in Tunisia. World J. Microbiol Biotechnol., 23, 1195-2001.

Christie S.R., Purcifull D.E., Crawford W.E. and Ahmed N.A. 1987. Electron microscopy of negative stained clarified viral concentrates obtained from small tissue samples with appendices on negative stain ing techniques. Fla. Agric. Exp. Stn. Technical Bulletin 872 p.

Elsheikh E.A.E. and Osman A.G. 1995. Rhizobium leguminosarum inoculation decreases damage to faba bean (Vicia faba) caused by broad bean mottle bromovirus and bean yellow mosaic potyvirus. World J. of Microbiology \& Biotechnology 11, 223-227.

Gibson A.H. 1987. Evaluation of nitrogen fixation by legumes in the greenhouse and growth chamber. In: Elkan GH, editor. Symbiotic nitrogen fixation technology. New York: Marcel Dekker, Inc. pp. 321-363.

Gonsalves D. and Ishii M. 1980. Purification and serology of papaya ringspot virus. Phytopathology 70, 1028-1032.

Guy P., Gibbas A. and Harrower K. 1980. The Effect of White Clover Mosaic Virus on Nodulation of White Clover (Trifoliumrepens L. cv. Ladino) Aust. J. Agric. Res., 31, 307-311.

Hampton R., Ball E. and De Boer S. 1990. Serological methods for detection and identification of viral and bacterial plant pathogens. A laboratory manual. The American Phytopathological Society, St. Paul, Minnesota, USA, 389 p.

Horn N.M., Reddy, S.V. and Reddy D.V.R. 1995. Assessment of yield losses caused by chickpea chlorotic dwarf geminivirus in chickpea (Cicer arietinum) in India. European J. of Plant Pathology 101, 221-224. 

of chickpea yellow mosaic virus

Hungria M., Joseph C.M. and Phillips D.A. 1991. Rhizobium nod gene inducers exuded naturally from roots of common bean (Phaseolus vulgaris L.) Plant Physiol., 97, 759-764.

Jordan D.C. 1984. Rhizobiaceae conn 1938. In: Bergey's Manual of Systematic Bacteriology (Eds. NR Krieg, JG Holt). Williams and Wilkins, Baltimore, London, pp. 235-244.

Joshi H.U., CARR A.J.H. and JONES D.G. 1967. Effect of Clover Phyllody Virus on Nodulation of White Clover (Trifolium repens) by Rhizobium trifolii, J. Gen. Microbiol. 47, 139-151.

Kacem M., Kazouz F., Merabet C., Rezki M., de Lajudie P. and Bekki Abdelkader. 2009. Antimicrobial activities of Rhizobium sp. strains against Pseudomonas savastanoi, the agent responsible for the olive knot disease in Algeria. Grasasy Aceites. 60, 139-146.

Kaiser W.J., Ghanekar A.M., Nene Y.L., Rao B.S. and Anjaiah V. 1990. ICRISAT (International Crops Research Institute for the SemiArid Tropics). 1990. Chickpea in the Nineties: proceedings of the Second International Workshop on Chickpea Improvement, 4-8 Dec 1989, ICRISAT Center, India. Patancheru, A.P. 502 324, India: ICRISAT, 403 p.

Kantar F., Elkoca E., Ögütçü H., Algur ÖF. 2003. Chickpea yields in relation to Rhizobium inoculation from wild chickpea at high altitudes. J. Agronomy and Crop Sci. 189, 291-297.

López M., Muñoz N., Lascano H.R. and Izaguirre-Mayoral M.L. 2016. The seed-borne Southern bean mosaic virus hinders the early events of nodulation and growth in Rhizobium- inoculated Phaseolus vulgaris L. Functional Plant Biology 44, 208-218.

Madsen L.H., Tirichine L., Jurkiewicz A., Sullivan J.T., Heckmann A.B., Bek A.S., Ronson C.W., James E.K. and Stougaard J. 2010. The molecular network governing nodule organogenesis and infection in the model legume Lotus japonicus. Nat Commun. pp. 1-10.

Masson-Boivin C., Giraud E., Perret X. and Batut J. 2009. Establishing nitrogen-fixing symbiosis with legumes: how many rhizobium recipes? Trends Microbiol 17, 458-466.

Öğütcü H., Algur Ö.F., Elkoca E. and Kantar F. 2008. The determination of symbiotic effectiveness of Rhizobium strains isolated from wild chickpea collected from high altitudes in Erzurum. Turk J Agric. For 32, 241-248.

Oldroyd G.E.D. and Downie J.A. 2008. Coordinating nodule morphogenesis with rhizobial in- fection in legumes. Ann. Rev Plant Biol 59, 519-546.

Osman A.G. and Elsheikh E.A.E. 1994. Possibility of controlling Bean yellow mosaic virus using nitrogen fixation in faba bean. Univ. of Khartoum J. of Agric. Sci., 2, 93-108.

Padmanabhan M.S., Shiferaw H. and Culver J.N. 2006. The Tobacco mosaic virus replicase protein disrupts the localization and function of interacting Aux/IAA proteins. Mol Plant Microbe Interact. 19, 864-873.

Padmanabhan M.S., Goregaoker S.P., Golem S., Shiferaw H. and Culver J.N. 2005. Interaction of the Tobacco mosaic virus replicase protein with the Aux/IAA protein PAP1, pp. 100-115.

Pande S. 2015. Effect of geminivirus infection on nodulation in cowpea. Scholars Research Library. Der Pharmacia Lettre, 7, 211-216.

Prevost D., Bordeleau LM., Caudry-Reznick S., Schulman HM. and Antoun H. 1987. Characteristics of rhizobia isolated from three legume indigenous to the Canadian high arctic Astragalus alpinus, Oxytropis maydelliana and Oxytropis arctobia. Plant and Soil 98, 313-324.

Rajagopal N. and Raju P.N. 1972. "The influence of infection by dolichos enation mosaic virus on nodulation and nitrogen fixation by field bean (Dolichos lablab L.)" Phytopath. Z., 73, 285 309.

Reed J.W. 2001. Roles and activities of Aux/IAA proteins in Arabidopsis. Trends Plant Sci. 6, 420-425.

Rohani B., Mosahebi G.H. and Habibi M.K. 2008. Nodule infection by bean yellow mosaic virus in Vicia faba and molecular characterization of it. Communications in Agric. and Applied Biological Sci. 73, 303-306.

Saharan B.S. and Nehra V. 2011. Plant Growth Promoting Rhizobacteria: A Critical Review. Life Sciences and Medicine Research, LSMR-21, 1-30.

Sarıoğlu G., Özçelik S. and Kaymaz S. 1993. Selection of effective nodosity bacteria (Rhizobium leguminosarum biovar. viceae) from lentil grown in Elazığ. Turk J. Agric. For 17, 569573.

Searle P.L. 1984. The Berthelot or indophenols reaction and its use in the analytical chemistry of nitrogen. Analyst 109, 549-568.

Sharma S.R. and Varma A. 1983. Effect of Cowpea Banding Mosaic Virus Infection on Nodulation and Nitrogen Fixation by Cowpea. Zentralblatt für Mikrobiologie. 138, 57-62. 
Tu J.C., Ford R.E. and Quiniones S.S. 1970. Effects of soybean mosaic virus and/or bean pod mottle virus infection on soybean nodulation. Phytopathology 60, 518-523.

Turner S., Pryer K.M., Miao V.P.W. and Palmer J.D. 1999. Investigating deep phylogenetic relationships among cyanobacteria and plastids by small subunit rRNA sequence analysis. J. of Eukaryotic Microbiology 46, 327-338.

Vincent J.M. 1970. A manual for practical study of root nodule bacteria. IBP Handbook No. 15, Blackwell Scientific Publishers, Oxford, 164 p.

Zanatta Z.G.C.N., Moura A.B., Maia L.C. and Santos A.S.D. 2007. Bioassay for selection of biocontroller bacteria against bean common blight (Xanthomonas axonopodis pv. phaseoli). Braz. J. Microbiol., 38, 511-515. 


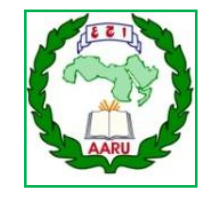

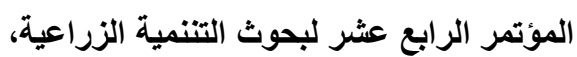

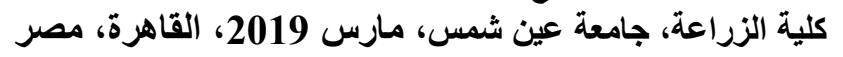

مجلا(27)، عدد(1)، عدد خاص مارس، مارس 205-193، 2019

Website: http://strategy-plan.asu.edu.eg/AUJASCI/

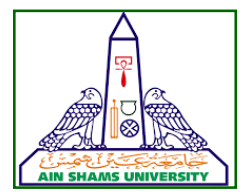

205

\section{تقييم الكفاءة التكاقلية للميزوريزوييوم فى تخفيض أعراض فيروس الموازيك \\ الأصفر فى الحمص}

[18]

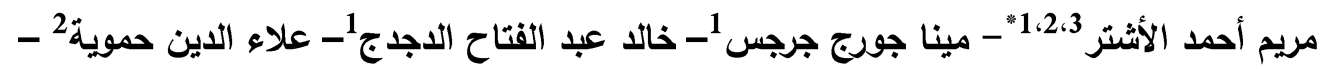
أحمد الفاتح الضليفي 3

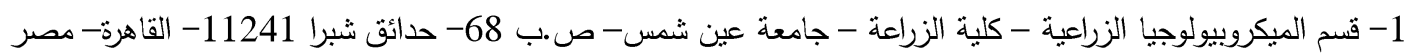

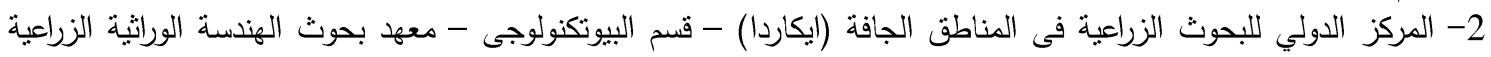

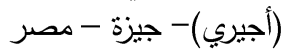

3- قسم البيولوجيا الجزيئية النباتية- دعمل نقنيات نعبير وتتظيم الجينات- معهد بحوث الهندة الوراثية الزراعية (أجيري)- جيزة-

*Corresponding author: maryamech@hotmail.fr

Received 9 September, 2018, Accepted 25 September, 2018

أثنارت النتائج إلى أن العدوى الفيروسية أدت إلى القى

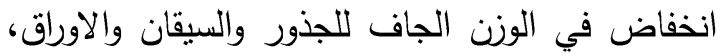

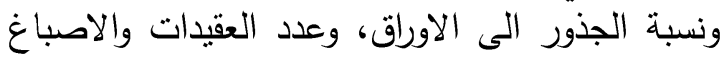
الضوئية، ومحتوى النتروجين، في هذه الأوراف، الأثناء، ازداد الادئ

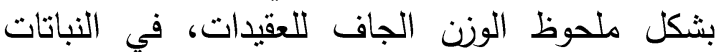

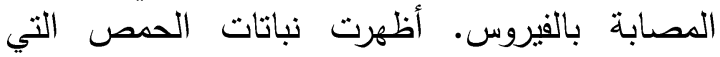

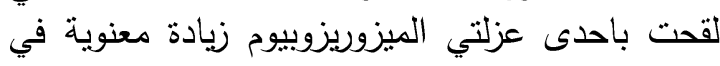

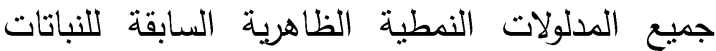

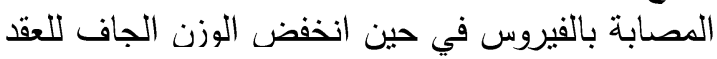

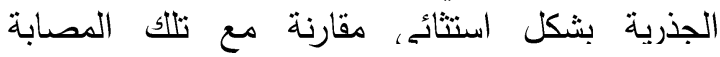

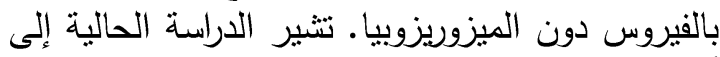
أن التلقيح البكتيري باستخدام Mesorhizobia يقلل التيزين بشكل كبير من الآثار التالفة للعدوى الفيروسية في

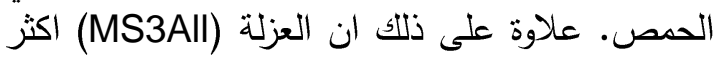

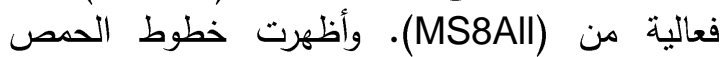
التجريبية (NF Parents, F. 07-258) و (NF) ) (Parents, F. 07-44 تفوق معنوي في محتوى

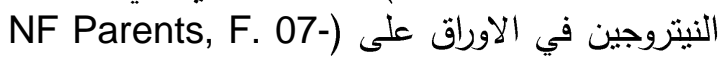
268) و (Giza 195).

الكلمات الدالة: ميزوريزوبيوم، حمص، فيروس موزايك الأصفر للحمص الأه:

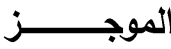

الحمص هو واحد من البقوليات التي تختزل نتروجين الهواء الجوي تكافليا هن خلاد الرئل الريزوبيا

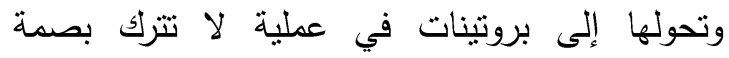

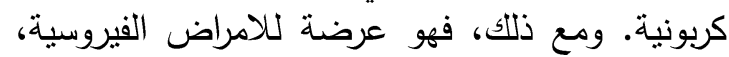

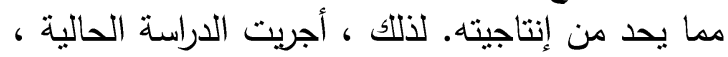

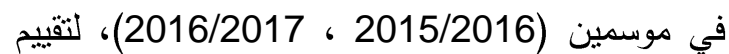
الفعالية التكافلية للميزوريزبيوم ( Mesorhizobium

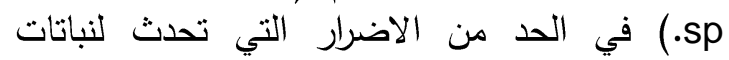
الحمص (Cicer arietinum L) في حالة الصابتها chickpea ) بفيروس موزاييك الحمص الاصفر (yellow mosaic virus (CpYMV) الغاية تم عزل فيروس واحد (CpYMV) وعزلتي ميزوريزوبيوم (MS3All, MS8All) من فئن الحقول المفتوحة لنباتات الحمص. ثلاثة انماط وراثية للحمص الحصن NF Parents, ) و (NF Parents, F. 07-268) (NF Parents, F. 07-44) , (F. 07-258 بالاضافة الى صنف حمص مصري (Giza 195)

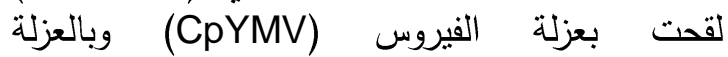

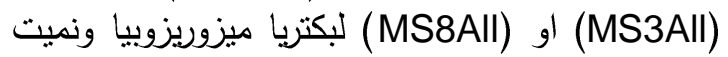
في اصص في كلية زراعة عين شمس، القاهرة، مصر . 